\title{
INTRODUCTION TO THE 2019 GENERAL EDITION
}

The Editorial Team of the Denning Law Journal are pleased to offer its 2019 General Edition, which covers a range of topical issues that fall within the remit of the journal and keeps faith with Lord Denning's vision and far-sightedness. The aim of the Denning Law Journal is to provide a forum for the widest discussion of issues arising in the common law world and the Commonwealth, and also to embrace wider global issues of contemporary concern.

Lord Denning recognised the importance of:

- developing the common law;

- focusing on the development of law in Commonwealth jurisdictions;

- the need for judicial and community recognition of the urgency of reform and modernisation of law;

- the need to preserve traditions of judicial independence, integrity, accountability and creativity;

- reflecting upon the interplay of law and morality;

- the role to be played by the state in the defence of the individual;

- international and comparative law;

- the protection and promotion of human and constitutional rights; and

- the development of constitutional and administrative law.

The Denning Law Journal strives to reflect these values and goals in every General Edition. We have two new features in this 2019 General Edition: the winner of our student writing competition and our Conversations section, which invites ongoing dialogue on important legal questions.

The winner of our student writing competition is Aidan Seymour-Butler. We are pleased to have students represented among our author contributors and will look to have further student writing competitions in the future.

Our Conversations section features an article by Professor Aliza Organick, on the value of state apologies, and what role these play in state-indigenous peoples relationships. This remains a vital issue in the twenty-first century and we invite comments in response, to foster an open and ongoing dialogue through our law journal.

As always, we are grateful for the invaluable assistance of our student editors in proofing this General Edition.

Sarah Sargent

James Slater

Editors 